\title{
A Systematic Review of Teacher Factors and Mathematics Achievement
}

\author{
Martina Maamin', Siti Mistima Maat ${ }^{2, *}$, Zanaton Ikhsan ${ }^{2}$ \\ ${ }^{1}$ Faculty of Education, Universiti Kebangsaan Malaysia, Malaysia \\ ${ }^{2}$ Center of Teaching and Learning Innovation, Faculty of Education, Universiti Kebangsaan Malaysia, Malaysia
}

Received December 31, 2019; Revised January 30, 2020; Accepted February 7, 2020

Copyright $\bigcirc 2020$ by authors, all rights reserved. Authors agree that this article remains permanently open access under the terms of the Creative Commons Attribution License 4.0 International License

\begin{abstract}
Mathematics is a fundamental subject to science, technology and engineering. Therefore, a good mathematics achievement is required for students to face the future challenges. However, the problem of low mathematics achievement still persists and one of the factors have been found to contribute to this problem that include teacher factors. Previous researchers have linked teacher factors with various elements such as teacher quality, teacher effectiveness, teaching practices, teacher characteristics, Teacher Pedagogical Content Knowledge (TPCK), teacher satisfaction and professional development. However, knowledge of the dominating teacher factors has been very limited in recent five years of research especially in mathematics achievement. Therefore, a systematic review will be conducted to identify the issue. The articles used in this review were accessed from January 2019 to June 2019 using the Scopus database and Clarivate Analytic Journal for Web of Science (WOS). To ensure that this review was done systematically, guidelines by Preferred Reporting Items for Systematic review and MetaAnalyzes (PRISMA) were used. It is found that the dominant of teacher factors that significant relation with student's mathematics achievement is teacher characteristics from dimension of teacher quality. Therefore, the stakeholder needs to emphasize on the teacher characteristics dimension of teacher quality to improve student's mathematics achievement.
\end{abstract}

Keywords Teacher Quality, Teacher Effectiveness, Teaching Practices, Teacher Characteristic, Teacher Pedagogical Content Knowledge (TPCK), Teacher Satisfaction, Professional Development, Mathematics Achievement

\section{Introduction}

Mathematical achievement is critical to ensuring that students continue to learn and to find good jobs in the future. Good mathematical achievement also reflects the mastery of the people of a country in science, technology and engineering. This is because mathematics is fundamental to science, technology and engineering. The mastery of the people of a country in science, technology and engineering is crucial because the competition in the era of globalization is now demanding that people effectively apply mathematical knowledge to the real world. However, to this day, the level of students' achievement in mathematics is still low. This evidence is based on the grades of their mathematics achievement in examinations conducted at school, national and international levels. Many studies have been conducted to study the factors contributing to this problem which includes factors of student (Ayotola \& Adedeji 2009; Hemmings et al. 2011; Murayama et al. 2013), teacher (Firmender et al. 2014; Hadley \& Dorward 2011), administrator (Kitsantas et al. 2011; Schreiber 2002) and family (Chiu \& Xihua 2008; Sheldon \& Epstein 2005; Yan \& Lin 2005). However, there are still shortcomings in previous studies, especially on teacher factors.

According to Goldhaber et al. (2019), teacher effectiveness has been found to be the most important school resource related with students achievement in particular students' mathematic achievement (Asadullah 2019). Previous researchers have linked teacher factors with various dimension such as teacher quality (DarlingHammond 2015; Goe 2007), teacher effectiveness (Campbell et al. 2012; Kearney \& Garfield 2019), teaching practices (Aslam \& Kingdon 2011; Blazar 2015), teacher experience (Fung et al. 2017; Hanushek \& Rivkin 2006), teacher characteristics (Armstrong 2015; Toropova et al. 2019), teacher qualifications (Buddin \& Zamarro 2009; Lydia \& Joash 2015) and teacher knowledge (Hill et al. 2005; Tengku Zawawi et al. 2009). However, knowledge of the dominating factors of teachers has been very limited in recent five years of research especially in mathematics 
achievement. It is important to identify dominating factors of teachers in student's mathematic achievement. This is because from the information, the stakeholders can make effective plans for improving student's mathematics achievement. Therefore, the purpose of this review is to identify the dominating teacher factors in student's mathematics achievement. This systematic review was conducted in accordance with the guidelines issued by Preferred Reporting Items for Systematic review and Metaanalyzes (PRISMA).

\section{Materials and Methods}

Line guidance issued by PRISMA was used to conduct a systematic review on teacher factors and mathematics achievement. Article sources were derived from Scopus and Web of Science (WOS) considering some of the conditions set by the steps of the review process (identification, screening and eligibility) as well as data abstraction and analysis.

\subsection{PRISMA}

This review was guided by the PRISMA Statement (Preferred Reporting Items for Systematic reviews and Meta-Analyses). According to Sierra-Correa and Cantera Kintz (2015), it offers three unique advantages which are 1) defining clear research questions that permits a systematics research, 2) identifying inclusion and exclusion criteria and 3) attempting to examine large database of scientific literature in a defined time. The PRISMA Statement allows for rigorous search of terms related to teacher quality and student achievement.

\subsection{Resources}

The review depends on two main journal database Scopus and Web of Science (WoS). WoS is a vigorous database consisting of > 33,000 journals with coverage of over 256 disciplines including subjects related to environmental studies, social issues, interdisciplinary social science and planning and development. WOS includes over 100 years of extensive back file and citation data, stable by Clarivate Analytics and grad them by three separate measures: citations, paper and citations per-paper.
Second database used in this review is Scopus. It had abstract and citation database of peer-review literature with more than 22,800 journals from 5000 publishers worldwide. Scopus can also be found in diverse subject areas such as social sciences, environmental science and biological science and agriculture.

\subsection{Eligibility and Exclusion Criteria}

Reviewers have identified several eligibility and exclusion criteria. Firstly, note to literature type which only journal articles are selected which means books, book series, book chapters and conference proceeding are excluded. Second, with regards to avoid any distraction and difficulty in translating, the searching attempt excluded the non-English publication and extracted only on articles published in English. Thirdly, regarding to timeline, a period of 5 years is selected (between 2015 and 2019), an acceptable period of time to examine the growth of research and related publications. As the review process focused on element of teacher factors towards mathematics achievement, indexed articles in social sciences based are selected, which means, articles issued in hard science index (Science Citation Indexed Expanded) are excluded.

\subsection{Systematic Review Process}

Four phases were engaged with the systematic review process. The survey procedure was performed in January 2019. The primary stage recognized keywords were utilized in the research process. Depending on past investigations, thesaurus, catchphrases comparative which were identified with teacher factors and mathematics achievement were used (Table 2). At this stage, after cautious screening, two copies of articles were expelled. The subsequent stage was screening, at this stage, out of 709 articles qualified to be checked on, an aggregate of 203 articles were evacuated. The third stage is eligibility, where the full articles were obtained. After cautious assessment, an aggregate of 45 articles were avoided as some did not concentrate on inland cultivating networks, were not experimental articles, did not canter on adjustment rehearses or did not concentrate on teacher factors and mathematics achievement. The last phase of survey brought about a sum of 40 articles that were utilized for the subjective examination (see Fig. 1).

Table 1. The inclusion and exclusion criteria

\begin{tabular}{|c|c|c|}
\hline Criterion & Eligibility & Exclusion \\
\hline Literature type & Journal (research articles) & $\begin{array}{c}\text { Journals (systematic review), book series, book, chapter in book, conference } \\
\text { proceeding }\end{array}$ \\
\hline Language & English & Non-English \\
\hline Time line & Between 2015 and 2019 & $<2015$ \\
\hline
\end{tabular}


Table 2. The search string used for the systematic review process.

\begin{tabular}{|c|c|}
\hline Databases & Keywords used \\
\hline Scopus & $\begin{array}{l}\text { TITTLE-ABS- KEY(("teacher* quality" OR "teacher*qualifications" OR "teacher* characteristics" OR } \\
\text { "teacher* practices" OR "teacher* effectiveness") AND ("mathematics achievement" OR "mathematics } \\
\text { performances" OR "students achievement" OR "students' performance")) }\end{array}$ \\
\hline Web of Science & $\begin{array}{l}\text { TS=(("teacher* quality" OR "teacher*qualifications" OR "teacher* characteristics" OR "teacher* practices" } \\
\text { OR "teacher* effectiveness") AND ("mathematics achievement" OR "mathematics performances" OR } \\
\text { "students achievement" OR "students' performance")) }\end{array}$ \\
\hline
\end{tabular}
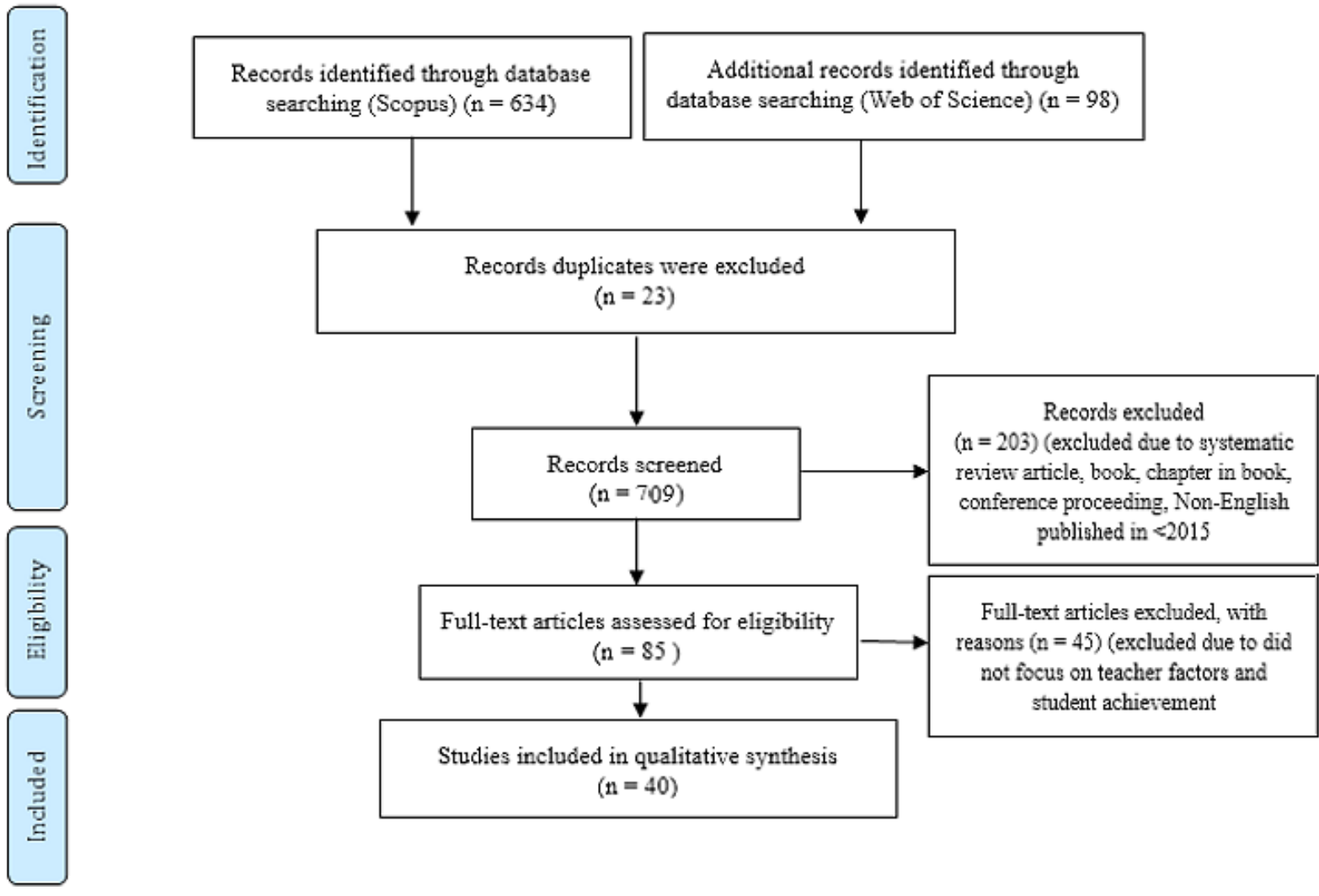

Figure 1. The flow diagram of the study(Adapted from Moher et al. 2009)

\subsection{Data Abstraction and Analysis}

The rest of the articles were surveyed and examined. Endeavors were focused on explicit investigations that reacted to the figured inquiries. The information was removed by perusing the edited compositions first where at that point are the full articles (top to bottom) to recognize fitting topics and sub-subjects. Subjective examination was performed utilizing investigation content to associate subjects identified with teacher factors and mathematics achievement. The creators at this point composed subsubjects around the topics built up by typology.

\section{Results}

The review resulted in seven construct teacher factors. The constructs are teacher quality, teacher effectiveness, teaching practices, teacher characteristics, teacher pedagogical content knowledge, teacher satisfaction and professional development. These constructs and dimension are taken into account based on statements made by the researcher (Table 3). Therefore, there is an overlap of dimension in the constructs of teachers' factors in the explanation. This is because researchers do not specify the teacher factors in their study as teacher quality. 
Table 3. The finding.

\begin{tabular}{|c|c|c|c|c|c|c|c|c|c|}
\hline No. & Authors/countries & Main study design & TQ & TE & TP & $\mathrm{TC}$ & TPCK & TS & PD \\
\hline 1 & Bhai and Horoi (2019) & QN & $\sqrt{ }$ & & & & & & \\
\hline 2 & O’Dwyer et al. (2015) & QN & & & $\sqrt{ }$ & & & & \\
\hline 3 & Kearney and Garfield (2019) & QN & & $\sqrt{ }$ & & & & & \\
\hline 4 & Tourón et al. (2018) & QN & & & $\sqrt{ }$ & & & & \\
\hline 5 & Adnot et al. (2017) & QN & $\sqrt{ }$ & & & & & & \\
\hline 6 & Aziqwe et al. (2016) & QN & & & $\sqrt{ }$ & & & & \\
\hline 7 & Bacher-Hicks et al. (2019) & QN & $\sqrt{ }$ & & & & & & \\
\hline 8 & Canales and Maldonado (2018) & QN & $\sqrt{ }$ & & & & & & \\
\hline 9 & Blömeke and Olsen (2019) & QN & & & & $\sqrt{ }$ & & & \\
\hline 10 & Talancé (2016) & QN & $\sqrt{ }$ & & & & & & \\
\hline 11 & Cordero \& Gil (2018) & QN & & & $\sqrt{ }$ & & & & \\
\hline 12 & Kraft (2012) & QN & $\sqrt{ }$ & & & & & & \\
\hline 13 & Reddy et al. (2019) & QN & & & $\sqrt{ }$ & & & & \\
\hline 14 & Ortega et al. (2018) & QN & & & & $\sqrt{ }$ & & & \\
\hline 15 & Lee (2018) & QN & $\sqrt{ }$ & & & & & & \\
\hline 16 & Torres (2018) & QN & $\sqrt{ }$ & & & & & & \\
\hline 17 & Gershenson (2018) & QN & $\sqrt{ }$ & & & & & & \\
\hline 18 & Asadullah (2019) & QN & & $\sqrt{ }$ & & & & & \\
\hline 19 & Burns et al. (2019) & QN & & & $\sqrt{ }$ & & & & \\
\hline 20 & Burroughs et al. (2019) & QN & $\sqrt{ }$ & & & & & & \\
\hline 21 & Gerritsen et al. (2016) & QN & $\sqrt{ }$ & & & & & & \\
\hline 22 & Lynch et al. (2017) & QN & $\sqrt{ }$ & & & & & & \\
\hline 23 & Cueto et al. (2016) & QN & & & & & $\sqrt{ }$ & & \\
\hline 24 & Dimosthenous et al. (2019) & QN & & $\sqrt{ }$ & & & & & \\
\hline 25 & Marcenaro-Gutierrez et al. (2015) & QN & & & & & & $\sqrt{ }$ & \\
\hline 26 & Klusmann et al. (2016) & QN & & & & & & & \\
\hline 27 & Zakharov et al. (2016) & QN & & & & $\sqrt{ }$ & & & \\
\hline 28 & Mogwathi et al. (2018) & QN & & & & & & $\sqrt{ }$ & \\
\hline 29 & Cowan and Goldhaber (2015) & QN & & $\sqrt{ }$ & & & & & \\
\hline 30 & Çakır and Bichelmeyer (2016) & QN & & & & $\sqrt{ }$ & & & \\
\hline 31 & Son et al. (2016) & QN & & & $\sqrt{ }$ & & & & \\
\hline 32 & Azam and Kingdon (2015) & QN & $\sqrt{ }$ & & & & & & \\
\hline 33 & Ing et al. (2015) & QN & & & $\sqrt{ }$ & & & & \\
\hline 34 & Polly et al. (2015) & QN & & & & & & & $\sqrt{ }$ \\
\hline 35 & Meroni et al. (2015) & QN & $\sqrt{ }$ & & & & & & \\
\hline 36 & Shuls and Trivitt (2015) & QN & $\sqrt{ }$ & & & & & & \\
\hline 37 & Suviste et al. (2016) & QN & & & $\sqrt{ }$ & & & & \\
\hline 38 & Thomas et al. (2018) & QL & & & $\sqrt{ }$ & & & & \\
\hline 39 & Miao et al. (2015) & MM & & & $\sqrt{ }$ & & & & \\
\hline 40 & Chu et al. (2015) & QN & $\sqrt{ }$ & & & & & & \\
\hline
\end{tabular}

TQ=Teacher Quality, TPCK=Teacher Pedagogical Content Knowledge, TE=Teacher Effectiveness, TS=Teacher Satisfaction, TP=Teaching Practices, $\mathrm{PD}=$ Professional Development, TC=Teacher Characteristics, $\mathrm{QN}=$ Quantitative, $\mathrm{QL}=\mathrm{Qualitative}, \mathrm{MM}=$ Mixed Method 


\subsection{Relationship between Teacher Factors and Mathematics Achievement}

This section concentrates on relationship between teacher factors and mathematics achievement such as teacher quality, teacher effectiveness, teaching practices, teacher characteristics, teacher pedagogical content knowledge, teacher satisfaction and professional development.

\subsubsection{Teacher Quality}

A total of 16 of 40 studies focus on teachers' quality with mathematics achievement (Bhai \& Horoi 2019; Canales \& Maldonado 2018; Talancé 2016; Torres 2018; Gerritsen et al. 2018; Shuls \& Trivitt 2015; Gershenson 2018; Azam \& Kingdon 2015; Burroughs 2019; Lynch 2017; Lee 2018; Chu et al. 2018; Adnot et al. 2018; Kraft 2015; Meroni et al. 2015; Bacher-Hicks 2019). Some researchers refer teacher quality with similar constructs but some are different. The summary is shown in the Table 4.

Table 4. Teacher quality

\begin{tabular}{|c|c|}
\hline Authors (Years) & Dimension \\
\hline $\begin{array}{c}\text { Bhai \& Horoi (2019) } \\
\text { Canales \& Maldonado (2018) } \\
\text { Talancé (2016) } \\
\text { Torres (2018) } \\
\text { Gerritsen et al. (2018) } \\
\text { Shuls \& Trivitt (2015) }\end{array}$ & Teacher characteristics \\
\hline $\begin{array}{c}\text { Lee (2018) } \\
\text { Gershenson (2018) } \\
\text { Azam \& Kingdon (2015) }\end{array}$ & Teacher effectiveness \\
\hline $\begin{array}{c}\text { Burroughs (2019) } \\
\text { Lynch (2017) }\end{array}$ & Teaching practices \\
\hline $\begin{array}{c}\text { Lee (2018) } \\
\text { Chu et al. (2018) }\end{array}$ & Teacher qualification \\
\hline $\begin{array}{c}\text { Adnot et al. (2018) } \\
\text { Kraft (2015) }\end{array}$ & Teacher turnover \\
\hline Meroni et al. (2015) & Teacher skill \\
\hline Bacher-Hicks (2019) & Teacher performance \\
\hline
\end{tabular}

Based on the literature review it was found that there are seven dimensions of teacher quality derived from 16 studies. These dimensions are teacher characteristics, teacher effectiveness, teaching practices, teacher qualification, teacher turnover, teacher skill and teacher performance. 6 of 16 studies focus on teacher characteristics. Finding of this review consistent with Goe (2007) that claim teacher quality has defined and measure in many ways.

We also found that each dimension is measured using different elements such as teachers' salary records (Bhai \& Horoi 2019; Talancé 2016), teaching experience (Bhai \& Horoi 2019; Canales \& Maldonado 2018; Talancé 2016; Gerritsen et al. 2018; Shuls \& Trivitt 2015), achievement and professional certificates (Bhai and Horoi 2019; Shuls \& Trivitt 2015; Talancé 2016), teacher gender (Canales \& Maldonado 2018; Talancé 2016; Gerritsen et al. 2018), years of professional experience (Canales \& Maldonado
2018), measure post-graduate credential (Canales \& Maldonado 2018), measure the institution where the teacher studied (Canales \& Maldonado 2018), teacher baccalaureate degree (Canales \& Maldonado 2018, Talancé (2016), local teacher (Talancé 2016), teacher training (Talancé 2016), bonus and teacher other work (Talancé 2016). Torres (2018) examine teacher characteristics as mathematics teacher and teaching same student in $9^{\text {th }}$ and $10^{\text {th }}$ grade.

Finding of the studies found that teacher experience and National Board Certification have positive and significant effect with student achievement (Bhai \& Horoi 2019). However, Canales \& Maldonado (2018) found teacher experience have non-linear relation with student's achievement. The finding is consistence with others study such as Ayieko et al. (2018), Nkrumah (2018) and Toropova et al. (2019) claim that teacher experience has non-linear relation with student achievement. In addition, Talancé (2016) found that teacher experience and education give little effect on student's mathematics achievement.

Another dimension of teacher quality that found in this review are teacher effectiveness (Lee 2018; Gershenson 2018; Azam \& Kingdon 2015), teaching practices (Burroughs 2019; Lynch 2017), teacher qualification (Lee 2018; Chu et al. 2018), teacher turnover (Adnot et al. 2018; Kraft 2015), teacher skill (Meroni et al. 2015) and teacher performance (Bacher-Hicks 2019). This study also found that student teaching by highly qualified teacher has a positive learning outcome (Gershenson 2018).

\subsubsection{Teacher Effectiveness}

A total of 4 out of 40 studies focus on teacher effectiveness to cope mathematics achievement. The first study from Kearney and Garfield (2019) identifies the effectiveness of teachers from the point of view of students. Item for measuring teacher effectiveness in this study were teachers reach the highest levels of student difficulty, teachers' self-confidence in motivating their students, teachers will give up when students don't want to learn, teachers have no teaching skills, teachers believe that every student can learn and teachers lack the skills to handle discipline problems. The second study from Asadullah (2019) examine teacher effectiveness used value-added model. Cowan and Goldhaber (2015) using teachers certified by the National Board for Professional Teaching Standards (NBPTS) to identify teacher effectiveness. Dimosthenous et al. (2019) investigated teacher effectiveness using model dynamic effectiveness (Creemers \& Kyriakides 2009).

Although these studies measure teachers' competence in different ways, it is found that 3 of 4 studies found significant relation with mathematics achievement (Kearney \& Garfield 2019; Cowan and Goldhaber 2015; Dimosthenous et al. 2019). Except Asadullah (2019) argues that weaknesses in measurement method. 


\subsubsection{Teaching Practices}

A total of 12 out of 40 studies focus on teaching practice to cope mathematics achievement (O'Dwyer et al. 2015; Tourón et al. (2018); Aziqwe et al. 2016; Cordero \& Gil 2018; Reddy at al. 2018; Dimosthenous et al. 2019; Son et al. 2016; Ing et al. 2016; Suviste et al. 2016; Thomas et al. 2018; Miao et al. 2015; Burns et al. 2019).

The results of 11 out of 12 studies found that teacher teaching practices were significantly associated with mathematics achievement (O'Dwyer et al. 2015; Aziqwe et al. 2016; Cordero \& Gil 2018; Reddy at al. 2018; Dimosthenous et al. 2019; Son et al. 2016; Ing et al. 2016; Suviste et al. 2016; Thomas et al. 2018; Miao et al. 2015; Burns et al. 2019). While the finding of Tourón et al. (2018) study did not support. Burns et al. (2019) found that teacher feedback-feedforward is related with student's mathematics achievement. Teacher feedback-feedforward will help student to revise their mathematics exercise. It helps student to identify their weakness in certain topic. From that, students can learn from a mistake. this situation will help students improve their understanding and improve mathematical achievement. The results of this study highlight the importance of teacher teaching practices in improving student mathematics achievement.

\subsubsection{Teacher Characteristics}

A total of 4 out of 40 studies focused on teacher characteristics to cope with students' achievement (Blömeke and Olsen 2019; Ortega et al. 2018; Zakharov et al. 2016; Çakır and Bichelmeyer 2016). Researchers refer teacher characteristics as Table 5 .

Table 5. Teacher characteristics

\begin{tabular}{|c|l|}
\hline Author (Years) & Teacher characteristics \\
\hline $\begin{array}{c}\text { Blömeke and Olsen } \\
\text { (2019) }\end{array}$ & $\begin{array}{l}\text { Teacher education major, teaching } \\
\text { experience, professional development, } \\
\text { preparedness and instructional quality }\end{array}$ \\
\hline Ortega et al. (2018) & $\begin{array}{l}\text { Teacher gender, certification, years of } \\
\text { teaching experience, being trained in } \\
\text { programs with subject specialization and } \\
\text { strong practicum component }\end{array}$ \\
\hline Zakharov et al. (2016) & $\begin{array}{l}\text { Teacher test score, teacher gender, } \\
\text { teacher education, teacher subject } \\
\text { trained, teaching experience, principal } \\
\text { reported and school resources }\end{array}$ \\
\hline $\begin{array}{c}\text { Çakır and Bichelmeyer } \\
\text { (2016) }\end{array}$ & $\begin{array}{l}\text { Instructors' educational credentials, } \\
\text { professional experience, and beliefs } \\
\text { about the value of the program }\end{array}$ \\
\hline
\end{tabular}

The result from Blömeke and Olsen (2019), Ortega et al. (2018) and Zakharov et al. (2016) found significant relation with student's achievement. The finding of the studies consistent with Canales and Maldonado (2018); Talancé (2017) who claim that teacher characteristics is correlated with student's achievement. However, Çakır and Bichelmeyer (2016) found that certain teacher characteristics do not related with student's achievement. The finding of the study similar with Bhai \& Horoi (2019) who found that teacher experience and National Board Certification have positive and significant effect on student's achievement but not for advance degree.

\subsubsection{Teacher Pedagogical Content Knowledge (TPCK), \\ Teacher Satisfaction and Professional Development}

A total of 4 out of 40 studies focused on teacher pedagogical content knowledge (Cueto et al. 2016), teacher satisfaction (Marcenaro-Gutierrez et al. 2015; Mogwathi et al. 2018) and professional development (Polly et al. 2015) each. All studies link the variable with student's mathematics achievement. Due to the small number of these elements we have incorporated them.

First teacher factor in this section is TPCK. TPCK is a form of teacher understanding that combines content, pedagogy and learner characteristics in a unique way (Gudmundsdottir \& Shulman 1987). It is important for teacher to teach and student learning. A study linking TPCK with mathematical achievement has been conducted in Peru, a developing country. Cueto et al. (2016) analyses one of the areas TPCK which is knowledge of content and students. The result show that TPCK was positively associated with mathematics achievement and the younger male teacher which Spanish speaker had higher PCK score. It shows that the level of TPCK is also influenced by the characteristics of the teacher.

According to Marcenaro-Gutierrez et al. (2015), teacher satisfaction is one of the methods to motivation teacher and become high quality teacher. Teacher satisfaction also one of the teacher factors that researcher identify in student's mathematics achievement study. Marcenaro-Gutierrez et al. (2015) in their study found that teacher satisfaction was significant relationship with student's mathematics achievement. However, Mogwathi et al. (2018) found that teacher job satisfaction has not significant relationship with mathematics achievement. Other researcher must follow up this study to find differences result.

Professional development important for teacher to rise their motivation in teaching. Student achievement will be enhanced when taught by teachers participating in professional development programs (Sample McMeeking et al. 2012). A study of professional development by Polly et al. (2015) found that statistically significant relationship between teacher professional development and student's mathematics achievement. Teachers participating in professional development programs will increase their teachers' mathematical knowledge to teach. In turn, it can be applied to the teaching practice and enhances students' understanding of mathematical learning. Therefore, it is not possible that student mathematics achievement will also increase.

\subsection{Discussion}

This study has attempted to systematically analyze the existing literature on relationship teacher factors with 
mathematics achievement between 2015 until 2019. From the reviews we know that teacher factors are related to mathematic achievement. However, the latest dominant teacher factors that related with mathematics achievement is teacher quality. It highlights the importance of teacher quality in improving mathematics achievement. The finding of this review show that dimension of teacher quality that dominant is teacher characteristic. Although the measurement of teacher quality is different from other researcher but the result still shows the significant result with mathematics achievement. The contribution of this review is to the stakeholder to focus on teacher quality especially in teacher characteristics for rise student's mathematics achievement.

\subsection{Future Direction}

Most current article in this review are quantitative research. 38 of 40 studies are in quantitative meanwhile two in qualitative and mix-method each. So future research recommended to do qualitative study or mixed-method design. As suggested by the Merriam (2009), qualitative studies can explore, explain and understand research more detail. Also with mixed-method design, a more in-depth explanation may be provided (Creswell \& Clark 2018).

The finding has significant arrangement suggestions. The contribution of teacher factors to mathematics achievement needs to be explored in more depth, especially the involvement of quality teachers. The lack of quality research that leads to the teacher quality with mathematical achievement has hindered us from conducting this literature review. Therefore, it is recommended that more quality studies be conducted on this.

\section{Conclusions}

Studies on student's mathematics achievement have been ongoing since then (Kitsantas et al. 2011; Reynolds \& Walberg 1992; Zhou et al. 2020). Among the factors associated with this problem are principal leadership (Shin \& Slater 2010), parental (Kilic \& Askin 2014), teacher (Bhai \& Horoi 2019) and students (Herges et al. 2017). In order to help the stakeholders overcome this problem, many studies exploring teacher factors have been conducted (Bhai \& Horoi 2019; Blömeke \& Olsen 2019; Boonen et al. 2014; Burns et al. 2019; Woo \& Henfield 2016). However, the dominant teacher factor is not known to help distribute information to stakeholder. By using the systematic review, we found that the dominant teacher factor that related with student's mathematics achievement is teacher characteristics from dimension of teacher quality.

The review proposes two proposals for future examinations. To begin with, using academic databases and other search engines such as EBSCOhost, Emerald Full Text, Frost \& Sullivan, JSTOR, ERIC and Google Scholar.
It is hoped that by increasing the academic database and search engine it will increase the number of previous studies. Second, focus on teacher quality and mathematics achievement of high school students.

\section{Acknowledgements}

This research was supported by the grant from the Faculty of Education, Universiti Kebangsaan Malaysia; GG-2019-065.

\section{REFERENCES}

[1] Armstrong, P. 2015. Teacher characteristics and student performance: An analysis using hierarchical linear modelling. South African Journal of Childhood Education 5(2): $123-145$.

[2] Aslam, M. \& Kingdon, G. 2011. What can teachers do to raise pupil achievement? Economics of Education Review 30(3): 559-574.

[3] Aslam, M., Malik, R., Rawal, S., Rose, P., Vignoles, A., \& Whitaker, L. (2019). Methodological lessons on measuring quality teaching in Southern contexts, with a focus on India and Pakistan. Research in Comparative and International Education, 14(1), 77-98.

[4] Ayotola, A. \& Adedeji, T. 2009. The relationship between mathematics self-efficacy and achievement in mathematics. Procedia - Social and Behavioral Sciences 1(1): 953-957.

[5] Azam, M., \& Kingdon, G. G. (2015). Assesing teacher quality in India. Journal of Development Economics, 117, 74-83.

[6] Barni, D., Danioni, F., \& Benevene, P. (2019). Teachers' self-efficacy: The role of personal values and motivations for teaching. Frontiers in Psychology, 10(July), 1-7

[7] Bhai, M., \& Horoi, I. (2019). Teacher characteristics and academic achievement. Applied Economic, 00(00), 1-19.

[8] Blazar, D. 2015. Effective teaching in elementary mathematics: Identifying classroom practices that support student achievement. Economics of Education Review 48: 16-29.

[9] Blömeke, S., \& Olsen, R. V. (2019). Consistency of results regarding teacher effects across subjects, school level, outcomes and countries. Teaching and Teacher Education, 77, 170-182.

[10] Buddin, R. \& Zamarro, G. 2009. Teacher qualifications and student achievement in urban elementary schools. Journal of Urban Economics 66(2): 103-115.http://dx.doi.org/10.1 016/j.jue.2009.05.001.

[11] Byers, A. I., Cameron, C. E., Ko, M., LoCasale-Crouch, J., \& Grissmer, D. W. (2016). What preschool classroom experiences are associated with whether children improve in visuomotor integration?. Early Education and Development, 27(7), 976-1003. 
[12] Çakır, H. \& Bichelmeyer, B. A. (2016). Effect of teacher professional characteristics on student achievement: an investigation in blended learning environment with standards-based curiculum. Interactive Learning Environments, 24(1), 20-32.

[13] Campbell, J., Kyriakides, L., Muijs, D. \& Robinson, W. 2012. Assessing teacher effectiveness: Developing a differentiated model. Assessing Teacher Effectiveness: Developing a Differentiated Model

[14] Canales, A. \& Maldonado, L. (2018). Teacher quality and student achievement in Chile: Linking teachers' contribution and observable characteristics. International Journal of Educational Development, 60(2018), 33-50.

[15] Chiu, M. N. (2015). Family inequality, school inequalities, and mathematics achievement in 65 countries: Microeconomiec mechanisms of rent seeking and diminishing margical returns. Teachers College Record, 117(1).

[16] Chiu, M.M. \& Xihua, Z. 2008. Family and motivation effects on mathematics achievement: Analyses of students in 41 countries. Learning and Instruction 18(4): 321-336.

[17] Cordero, J. M., \& Gil, M. (2018). The effect of teaching strategies on student achievement: An analysis using TALIS-PISA. Journal of Policy Modeling.

[18] Cowan, J., \& Goldhaber, D. (2016). National board certification and teacher effectiveness: Evidence from Washington State. Journal of Research on Educational Effectiveness, 9(3), 233-258.

[19] Cueto, S., León, J., Sorto, M.A. \& Miranda, A. (2017). Teachers' pedagogical content knowledge and mathematics achievement of students in Peru. Educational Studies in Mathematics, 94(3): 329-345.

[20] Darling-Hammond, L. 2015. Teacher Quality and Student Achievement. Education Policy Analysis Archives 8(1): 1.

[21] Firmender, J.M., Gavin, M.K. \& McCoach, D.B. 2014 Examining the Relationship Between Teachers' Instructional Practices and Students' Mathematics Achievement. Journal of Advanced Academics 25(3): 214 236.

[22] Fitchett, P.G. \& Heafner, T.L. (2018). Teacher Quality or Quality Teaching? Eighth Grade Social Studies Teachers' Professional Characteristics and Classroom Instruction as Predictors of U.S. History Achievement. RMLE Online, 41(9), 1-17.

[23] Fung, D., Kutnick, P., Mok, I., Leung, F., Pok-Yee Lee, B., Mai, Y.Y. \& Tyler, M.T. 2017. Relationships between teachers' background, their subject knowledge and pedagogic efficacy, and pupil achievement in primary school mathematics in Hong Kong: An indicative study. International Journal of Educational Research 81: 119-130.

[24] Gerritsen, S., Plug, E. \& Webbink, D. (2016). Teacher Quality and Student Achievement: Evidence From A Sample Of Dutch Twins Sander. Journal of Applied Econometrics.

[25] Gershenson, S. (2016). Linking Teacher Quality, Student Attendance and Student Achievement. Education Finance and Policy, 1-25.
[26] Gess-Newsome, J., Taylor, J.A., Carlson, J., Gardner, A.L., Wilson, C.D., Stuhlsatz, M.A.M., Taylor, J.A., Carlson, J., Gardner, A.L., Wilson, C.D. \& Stuhlsatz, M.A.M. (2017). Teacher pedagogical content knowledge, practice, and student achievement. International Journal of Science Education, 0(0): 1-20.

[27] Glover, T.A., Kettler, R.J., Reddy, L.A. \& Kurz, A. (2019). Formative Assessment Approaches to Inform Teacher Practices: Key Considerations. Assessment for Effective Intervention, 44(2), 67-68.

[28] Goe, L. (2007). The Link Between Teacher Quality and Student Outcomes: A Research Synthesis. National Comprehensive Center for Teacher Quality, (October), 1-72.

[29] Hadley, K.M. \& Dorward, J. 2011. Investigating the Relationship between Elementary Teacher Mathematics Anxiety, Mathematics Instructional Practices, and Student Mathematics Achievement. Journal of Curriculum and Instruction 5(2): 27-44.

[30] Hall, T.J., Hicklin, L.K. \& French, K.E. (2017). Relationship of Teacher Training and School Characteristics to Middle School State Assessment Result. Journal of Teaching in Physical Education.

[31] Hanushek, E.A. \& Rivkin, S.G. 2006. Teacher Quality. Handbook of the Economics of Education Vol. 2, hlm. 1051-1078

[32] Hemmings, B., Grootenboer, P. \& Kay, R. 2011. Predicting mathematics achievement: The influence of prior achievement and attitudes. International Journal of Science and Mathematics Education 9(3): 691-705.

[33] Hill, H.C., Rowan, B. \& Ball, D.L. 2005. Effects of teachers' mathematical knowledge for teaching on student achievement. American Educational Research Journal 42(2): 371-406.

[34] Hynds, A. S., Hindle, R., Savage, C., Meyer, L. H., Penetito, W. \& Sleeter, C. (2016). The Impact of the Teacher Professional Development to Reposition Pedagogy for Indigenous Students in Mainstream Schools. The Teacher Educator, 51, 230-249.

[35] Ing, M., Webb, N. M. Franke, M. L., Turrou, A. C. Wong, J., Shin, N. \& Fernandez, C. H. (2015). Student participation in elementary mathematics classroom: the missing link between teacher practices and student achievement?. Educ Stud Math.

[36] Kearney, W.S. \& Garfield, T. 2019. Student Readiness to Learn and Teacher Effectiveness: Two Key Factors in Middle Grades Mathematics Achievement. RMLE Online 42(5): 1-12.https://doi.org/10.1080/19404476.2019.16071 38 .

[37] Kettler, R.J. \& Reddy, L.A. (2019). Using Observational Assessment to Inform Professional Development Decisions: Alternative Scoring for the Danielson Framework for Teaching. Assessment for Effective Intervention, 44(2), 6980 .

[38] Kitsantas, A., Cheema, J. \& Ware, H.W. 2011. Mathematics Achievement: The Role of Homework and Self-Efficacy Beliefs. Journal of Advanced Academics 22(2): 310-339.

[39] Klusmann, U. \& Richter, D. (2016). Teachers’ Emotional 
Exhaustion Is Negatively Related to Students' Achievement: Evidence From a Large-Scale Assessment Study. Journal of Educational Psychology, 108(8), 1193-1203.

[40] Lee, S. W. (2018). Pulling Back the Curtain: Revealing the Cumulative Importance of High-Performing, Highly Qualified Teachers on Students' Educational Outcome. Educational Evaluation and Policy Analysis, XX(X), 1-23.

[41] Lekwa, A., Reddy, L.A., Hua, A., Dudek, C. M.,Kettler, R. J., Arnold-Berkovits, I. \& Crouse, K. (2018). Use of observational measures to predict student achievement. Studies in educational Evalustion, 62(2019), 197-208.

[42] Lydia, M.M. \& Joash, A.M. 2015. Teacher qualification and students' academic performance in science mathematics and technology subjects in Kenya. International Journal of Educational Administration and Policy Studies 7(3): 83-89.

[43] Lynch, K., Chin, M. \& Blazar, D. (2017). Relationships between Observations of Elementary Mathematics Instruction and Student Achievement: Exploring Variability across Districts. American Journal of Education, 123(4), 615-646.

[44] Mantzicopoulos, P., Patrick, H., Strati, A. \& Watson, J.S. (2018). Predicting Kindergarteners' Achievement and Motivation From Observational Measure of Teaching Effectiveness. Journal of Experimental Education, 86(2), 214-232.

[45] Marcenaro-Gutierrez, O.D., Luque, M. \& Lopez-Agudo, L.A. (2016). Balancing Teachers' Math Satisfaction and Other Indicators of the Education System's Performance. Social Indicators Research, 129(3), 1319-1348.

[46] Meroni, E.C., Vera-Toscano, E. \& Costa, P. (2015). Can low skill teachers make good students? Empirical evidence from PIAAC and PISA. Journal of Policy Modeling, 37(2), 308323.

[47] Moher, D., Liberati, A., Tetzlaff, J. \& Altman, D.G. (2009). Academia and Clinic Annals of Internal Medicine Preferred Reporting Items for Systematic Reviews and MetaAnalyses. 151(4), 264-269.

[48] Murayama, K., Pekrun, R., Lichtenfeld, S. \& vom Hofe, R. 2013. Predicting long-term growth in students' mathematics achievement: The unique contributions of motivation and cognitive strategies. Child Development 84(4): 1475-1490.

[49] Nkrumah, M.A. (2018). The relevance of teacher factors in understanding tertiary students' performances. Quality Assurance in Education, 24(1), 251-267.

[50] O’Dwyer, L. M., Wang, Y. \& Shields, K. A. (2015). Teaching for conceptual understanding:A cross-national comparison of the relationship between teachers' instructional practices and student achievement in mathematics. Large-scale Assessments in Education.

[51] Polly, D., McGee, J., Wang, C., Martin, C., Lambert, R. \& Pugalee, D. K. (2015). Linking professional development, teacher outcomes, and student achievement: The case of a learner-centered mathematics program for elementary school teachers. International Journal of Educational Research, 72(2015), 26-37.

[52] Rietdijk, S., Janssen, T., van Weijen, D., van den Bergh, H. \& Rijlaarsdam, G. (2017). Improving writing in primary schools through a comprehensive writing program. Journal of Writing Research, 9(2), 173-225.

[53] Schreiber, J.B. 2002. Institutional and student factors and their influence on advanced mathematics achievement. Journal of Educational Research 95(5): 274-286.

[54] Sheldon, S.B. \& Epstein, J.L. 2005. Involvement Counts: Family and Community Partnerships and Mathematics Achievement. Journal of Educational Research 98(4): 196207.

[55] Shuls, J. V. \& Trivitt, J.R. (2015). Teacher Qualifications and Productivity in Secondary Schools. Journal of School Choice, 9(1), 49-70.

[56] Sierra-Correa, P.C., Ricardo, J. \& Kintz, C. (2015). Ecosystem-based adaptation for improving coastal planning for sea-level rise: A Systematic review for mangrove coasts. Marine Policy, 51, 385-393.

[57] Tengku Zawawi, T.Z., Ramlee, M. \& Abdul Razak, H. 2009. Pengetahuan Pedagogi Isi Kandungan Guru Matematik bagi Tajuk Pecahan: Kajian Kes di Sekolah Rendah. Jurnal Pendidikan Malaysia 34(1): 131-153.

[58] Toropova, A., Johansson, S., Myrberg, E., Toropova, A., Johansson, S. \& Myrberg, E. 2019. The role of teacher characteristics for student achievement in mathematics and student perceptions of instructional quality. Education Inquiry $0(0)$ : $1-25$.

[59] Torres, R. (2018). Tackling inequality? Teacher effects and the socioeconomic gap in educational achievement. School Effectiveness and School Improvement.

[60] Tourón, J., Navarro-Asencio, E., Lizasoain, L., LópezGonzález, E. \& García-San Pedro, M.J. (2019). How teachers' practices and students' attitudes towards technology affect mathematics achievement: result and insights from PISA 2012. Research Papers in Education, 34(3), 263-275.

[61] Wachen, J., Harrison, C. \& Cohen-Vogel, L. (2018). Data Use as Instructional Reform: Exploring Educators' Reports of Classroom Practice. Leadership and Policy in Schools, 17(2), 296-325

[62] Yan, W. \& Lin, Q. 2005. Parent Involvement and Mathematics Achievement: Contrast Across Racial and Ethnic Groups. Journal of Educational Research 99(2): $116-127$.

[63] Zakharov, A., Tsheko, G. \& Carnoy, Martin. (2016). Do "better" teachers and classroom resources improve student achievement? A causal comparative approach in Kenya, South Africa, and Swaziland. International Journal of Educational Development. 50(2016), 108-124. 